\title{
Grazing pressure of the calanoid copepod Temora longicornis on a Phaeocystis dominated spring bloom in a Dutch tidal inlet
}

\author{
F. C. Hansen ${ }^{1}$, W. H. M. van Boekel ${ }^{2}$ \\ ${ }^{1}$ Netherlands Institute for Sea Research, PO Box 59, 1790 AB Den Burg, The Netherlands \\ ${ }^{2}$ University of Groningen, Dept of Marine Biology, PO Box 14, 9750 AA Haren, The Netherlands
}

\begin{abstract}
Between 30 March and 11 May 1990, total copepod abundance and the abundance, biomass and gut fluorescence of Temora longicornis were determined and related to the abundance and succession of phytoplankton development in a Dutch tidal inlet. Gut pigment values were highest in females and lowest in young copepodites, but weight-specific pigment concentrations were about similar. Pigment levels measured in the guts were relatively high at the beginning and end of the period of investigation when diatoms dominated the phytoplankton community, and low during the Phaeocystis dominated period, when ambient chlorophyll concentrations were highest. For the latter period, calculated ingestion rates in $T$. longicornis were low and estimated daily consumption amounted to less than $1 \%$ of the phytoplankton standing stock, suggesting a negligible grazing impact on the development of the Phaeocystis bloom. In spite of the low grazing on phytoplankton, T. longicornis biomass increased by one order of magnitude. The discrepancy between low grazing pressure and copepod development is explained by assuming that $T$. Iongicornis switched to heterotrophic food: a bloom of ciliates present during the Phaeocystis dominated period.
\end{abstract}

\section{INTRODUCTION}

Copepod grazing has traditionally been regarded as having an important function in coupling phytoplankton to higher trophic levels, leading to fish production (Steele 1974). Increased nutrient inputs into North Sea coastal waters in the past 2 decades correlate not only with an increase in phytoplankton biomass but also with a shift in its community composition towards flagellates (Cadée 1986, Radach et al. 1990). In particular since 1973, blooms of the prymnesiophyte Phaeocystis sp. have increased (e.g. Cadée 1986), which has been reported to cause nuisances and possible economic drawbacks in fishery (e.g. Savage 1932) and tourism (Lancelot et al. 1987). Environmental problems are suspected from dimethylsulfide (DMS) release (Turner et al. 1988 and references cited therein) and mass production and sedimentation (Wassmann 1990) of organic matter, for which the impact on the benthic and pelagic food web structure is still unclear. Since 1988, Phaeocystis bloom dynamics have been studied by a group of European scientists within a joint EEC project. A major question to be answered is the ultimate fate of Phaeocystis and in this context the possible role of copepods in controlling Phaeocystis blooms.

The literature concerning copepod grazing on Phaeocystis is contradictory. On the one hand, Phaeocystis is regarded as unsuitable food (e.g. Schnack 1983, Daro 1986, Verity \& Smayda 1989). This holds for the colonies, because they are sticky and partly too large (up to ca $20 \mathrm{~mm}$ ), as well as for the small flagellates $(3$ to $8 \mu \mathrm{m}$ ) which are at the lower end of the size spectrum of retainable algae for most herbivorous copepods. Possible negative effects on copepods by the release of antibacterial acrylic acid (Sieburth 1960) and DMS (Gibson et al. 1990) have not yet been studied in detail. On the other hand, Phaeocystis ingestion by copepods has been reported (e.g. Lebour 1922, Estep et al. 1990) and recent laboratory studies quantifying grazing (Huntley et al. 1987, Tande \& Båmstedt 1987, Hansen et al. 1990) indicate that copepods are potential Phaeocystis consumers. In this respect, the calanoid copepod Temora longicornis 
seems to be a promising candidate, because of its high abundance during spring in North Sea coastal waters (e.g. Fransz \& van Arkel 1983 and references cited therein) and its ability to feed on Phaeocystis colonies (Weisse 1983) and single cells (F. Hansen unpubl. obs.).

There are strong indications that food quality and composition have a major impact on copepod grazing activity (e.g. Cowles et al. 1988, Estep et al. 1990, Klein Breteler et al. 1990, F. Hansen unpubl.). Differences in food quality and composition may also be responsible for contradictions in reports regarding copepod grazing on Phaeocystis in laboratory and field studies. Direct estimates of copepod grazing on a Phaeocystis bloom in the field are scarce and contradictory. This study measures Temora longicornis grazing activity in the course of a Phaeocystis dominated spring bloom in the field by means of the gut fluorescence method, in order to evaluate the importance of $T$. longicornis predation for Phaeocystis bloom dynamics.

\section{MATERIAL AND METHODS}

Samples were collected from the Marsdiep (Fig. 1), a eutrophicated and well-mixed tidal part of Dutch coastal waters. A detailed description of the hydrography of this area was given by Postma (1954). To follow phytoplankton and zooplankton development, quantitative surface water samples were taken frequently between 30 March and 11 May 1990, always at high tide. During this period, water temperature remained low until 24 April $\left(8\right.$ to $\left.10^{\circ} \mathrm{C}\right)$, with a subsequent rise to $14^{\circ} \mathrm{C}$ in mid-May.

Chlorophyll a (chl a) concentration in the samples was measured by applying the spectrophotometric method of Lorenzen (1967). Cell number and species composition of phytoplankton were determined with the Utermöhl sedimentation technique (Utermöhl 1958) in samples fixed with Lugol. Cell volumes of Phaeocystis and diatom species were determined by microscopical size measurements. Phytoplankton carbon was calculated by assuming that the chl a ratio Phaeocystis/diatoms equals the biovolume ratio Phaeocystis/diatoms in the samples and by applying a carbon/chl a ratio of 25 in diatoms (Riemann et al. 1982) and 29 in Phaeocystis (Lancelot-van Beveren 1980). The Phaeocystis colonies in the samples were all of the globosa-type (Jahnke \& Baumann 1987).

To collect copepods, $60 \mathrm{l}$ of water collected by bucket was poured into plastic bottles and gently filtered over a floating $300 \mu \mathrm{m}$ gauze. Retained plankton were rinsed on pieces of $200 \mu \mathrm{m}$ gauze and immediately deep-frozen by means of liquid nitrogen. Gauzes were

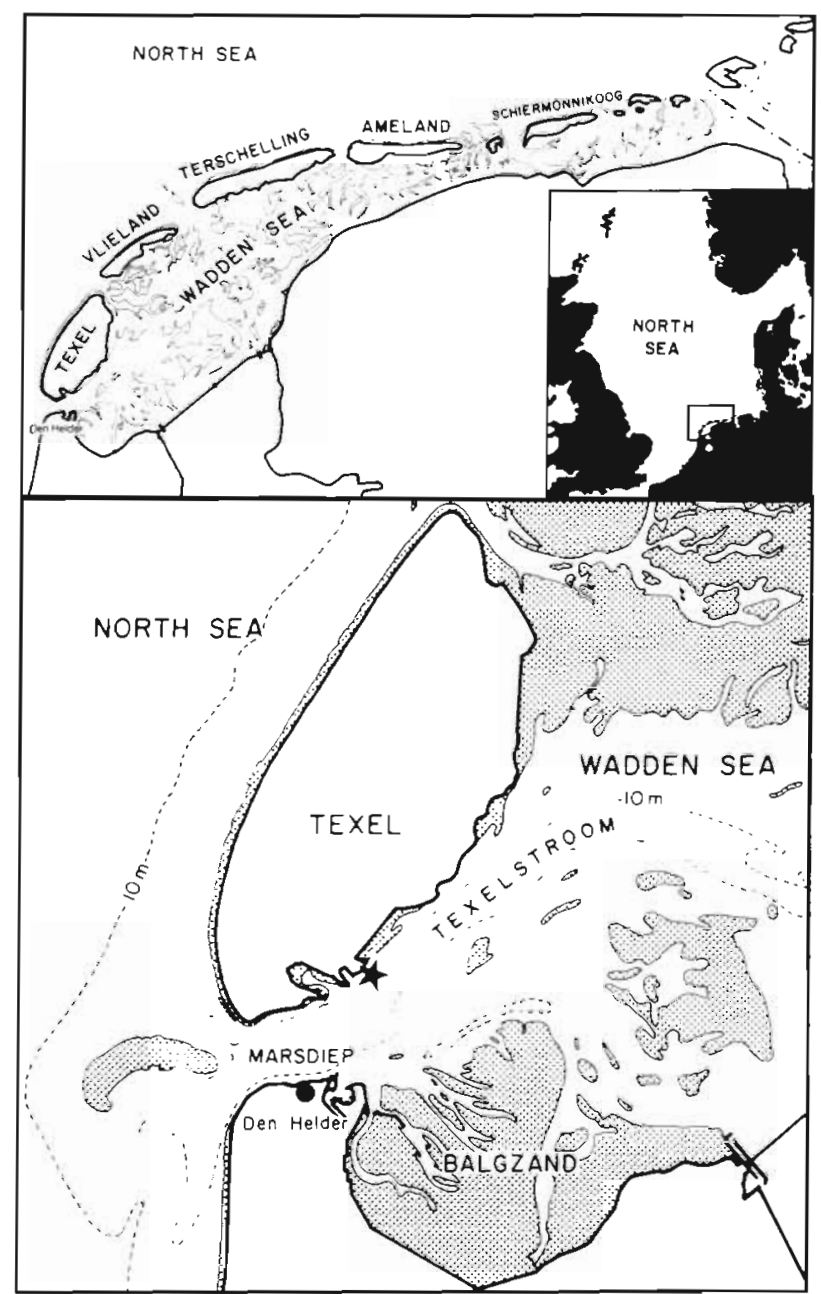

Fig. 1 Location of the Marsdiep area (asterisk indicates position of sampling site)

stored in the dark in Petri dishes at $-24^{\circ} \mathrm{C}$ for 2 to 4 mo. Copepods were collected from the gauzes and sorted for species under a dissecting microscope. Temora longicornis specimens were further sorted for sex and developmental stage, and their lengths measured. Young copepodite stages (stage $\leq \mathrm{C} 4$ ) were distinguished from older copepodites (stage C5 plus C6), which were separated into males and females.

Temora longicomis gut fluorescence was determined as described by Baars \& Oosterhuis (1984) with minor modifications. Copepods were homogenized using a Potter grinder. After $2 \mathrm{~h}$ of extraction in the dark at $5^{\circ} \mathrm{C}$, the solution was filtered through a GF/F filter mounted on a syringe. In the filtrate, chlorophyll $a$ and phaeopigment concentrations were measured and gut fluorescence was taken as the sum of chlorophyll a plus phaeopigments, expressed as ng chl a equivalent per copepod. In preliminary experiments background fluorescence and changes in pigment concentration 
due to storage and freezing were found to be negligible.

Gut pigment content (chl a plus derived phaeopigments) is expressed as ng chl a weight equivalent per copepod or per mg ash-free dry weight, calculated from size-weight relationships given by Klein Breteler \& Gonzales (1988). Temora longicornis body carbon was taken as $40 \%$ ash-free dry weight (Omori 1969). Copepod ingestion rates were calculated from gut fluorescence and temperature-dependent rates of gut clearance given by Dam \& Peterson (1988).

\section{RESULTS}

Between 30 March and 9 April 1990, the phytoplankton community in the Marsdiep was dominated by large diatoms (Biddulphia sinensis, Thalassiosira spp.). In the first half of April, both chl a and Phaeocystis cell concentration increased, with peaks on 13 and 15 April respectively (Fig. 2). At the peak of the Phaeocystis bloom, cell concentration exceeded $67 \times 10^{6}$ cells $^{-1}$ while the chlorophyll concentration amounted to $55 \mu \mathrm{g} \mathrm{chl} \mathrm{a} \mathrm{l^{-1 }}$ Thereafter, Phaeocystis cell density and chlorophyll concentration declined sharply. Between 11 and 24 April, phytoplankton biomass was dominated by Phaeocystis (Fig. 3). In the second half of April small diatom species (Plagiogramma brockmanni, Asterionella spp.) became increasingly important. Cerataulina bergonii dominated the phytoplankton community after 24 April. In the latter period, chlorophyll concentration decreased

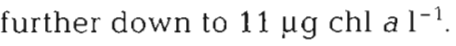

Copepod abundance remained low until mid-April, reaching significantly higher concentrations in the latter part of the investigation period (Fig. 4). Generally, Temora longicornis was the dominant copepod, comprising on average $80 \%$ of the total copepod

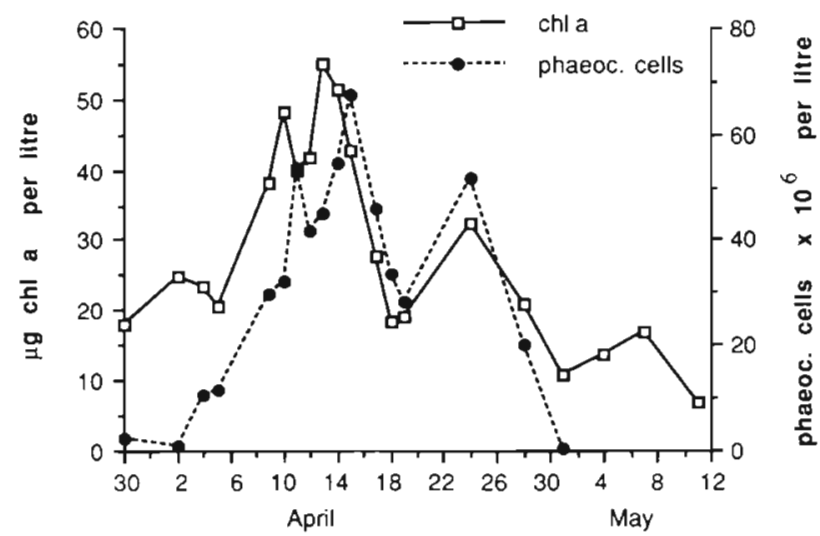

Fig. 2. Phytoplankton spring development in the Marsdiep from 30 March to 12 May 1990: chlorophyll a and Phaeocystis cell concentrations

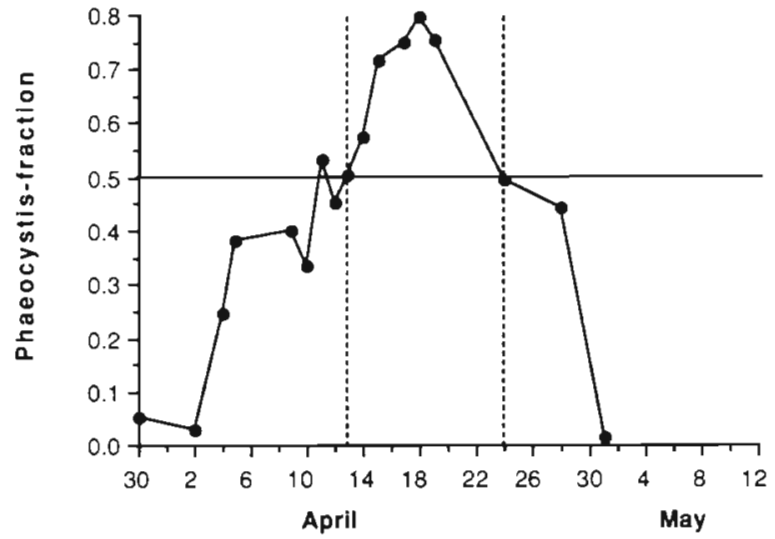

Fig. 3. Phaeocystis biovolume fraction of total phytoplankton biomass in Marsdiep. Vertical lines indicate period of Phaeocystis dominance

number. Other copepods mainly consisted of Pseudocalanus elongatus, which appeared in higher concentration during May. An attempt was made to estimate $T$. longicornis production from biomass increase in the larger copepodites by the application of an exponential growth model (Fig. 5). The significant regressions for females (1) and males (2), $\left(r_{1}{ }^{2}=0.80\right.$; $r_{2}^{2}=0.74 ; n_{1}, n_{2}=9 ; p_{1}, p_{2}<0.01$ ), yielded minimum $\mathrm{P} / \mathrm{B}$ ratios (including mortality, see 'Discussion') of $15 \% \mathrm{~d}^{-1}$, indicating good growth during the Phaeocystis dominated period.

Gut fluorescence of males and females (C5 + C6) and smaller copepodites did not resemble the course of the chlorophyll concentration in the water (Figs. $2 \& 6$ ), but appeared to be inversely correlated with Phaeocystis dominance (Fig. 3). During the Phaeocystis attributed chlorophyll increase, gut fluorescence declined, being lowest while Phaeocystis dominated the phytoplankton community. Thereafter in May, while the phytoplankton community was mainly composed of

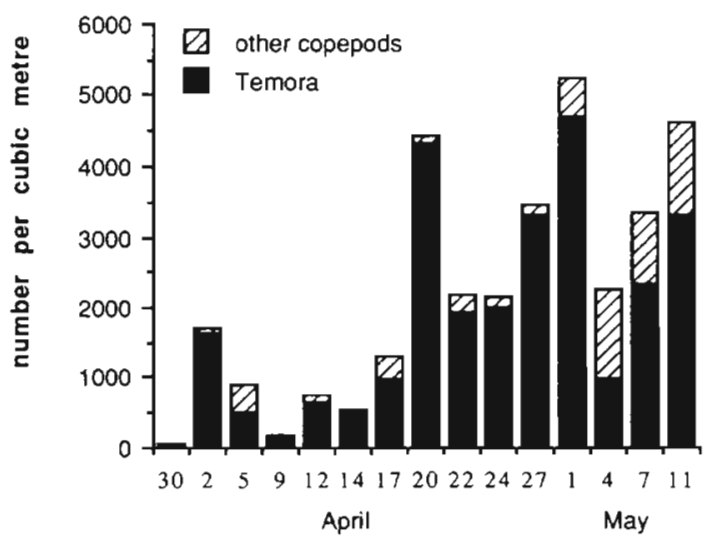

Fig. 4. Abundance of Temora longicornis and other copepod species in the Marsdiep in spring 1990 (mean concentrations of all stages concentrated on $300 \mu \mathrm{m}$ gauze) 


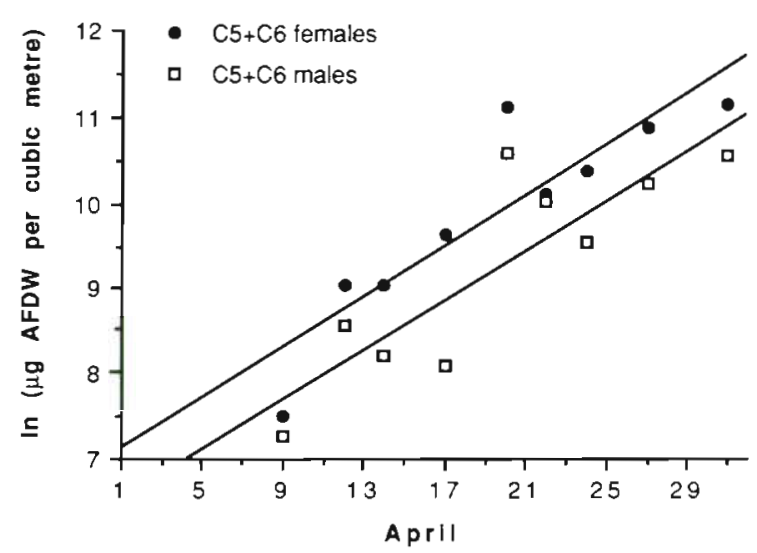

Fig. 5. Biomass of male and female C5 and adult Temora longicornis in the Marsdiep in spring 1990 (mean concentrations of all stages concentrated on $300 \mu \mathrm{m}$ gauze). Exponential growth curves fitted according to: $B_{t}=B_{0} \mathrm{e} \cdot \mathrm{B}^{-m}$ where $B_{0}, B_{i}$ : biomass at the beginning/end of studied period $t$ (in days); $P$ : production; $m$ : mortality. (For results, see text)

several small diatom species, gut fluorescence showed an increase of a factor of about 4 .

Generally females showed highest gut fluorescence males lower, and copepodites the lowest gut fluorescence (Fig. 6). However, after correcting for body size differences, by expressing gut fluorescence per unit ash-free dry weight (AFDW), the gut fluorescences of the different sexes and stages were almost the same or rather higher in the smaller stages (Fig. 7). In the diatom dominated periods, calculated ingestion rates were much higher in April/May compared to March/April (Table 1), partly due to the higher gut evacuation rates in the latter period with higher water temperature.

Total daily phytoplankton ingestion by Temora longicornis was low, especially during the Phaeocystis dominated period. In this period, total ingestion

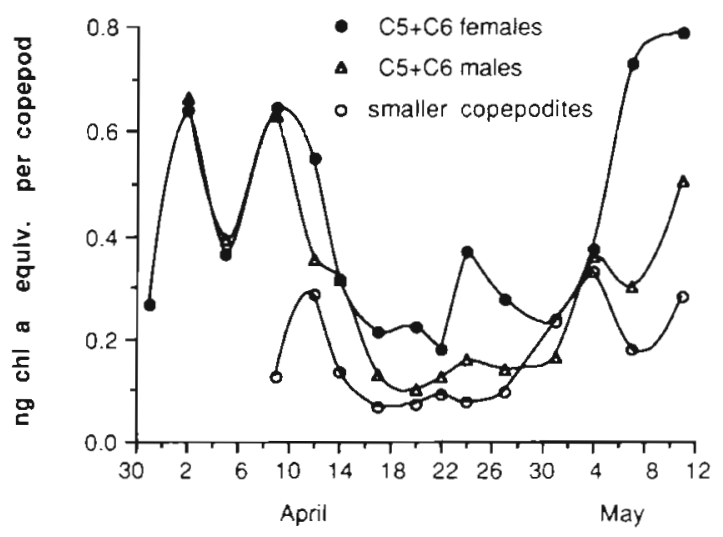

Fig. 6. Temora longicorns. Gut fluorescence of 3 age and sex classes in the Marsdiep during spring 1990 (mean concentrations of all stages concentrated on $300 \mu \mathrm{m}$ gauze)

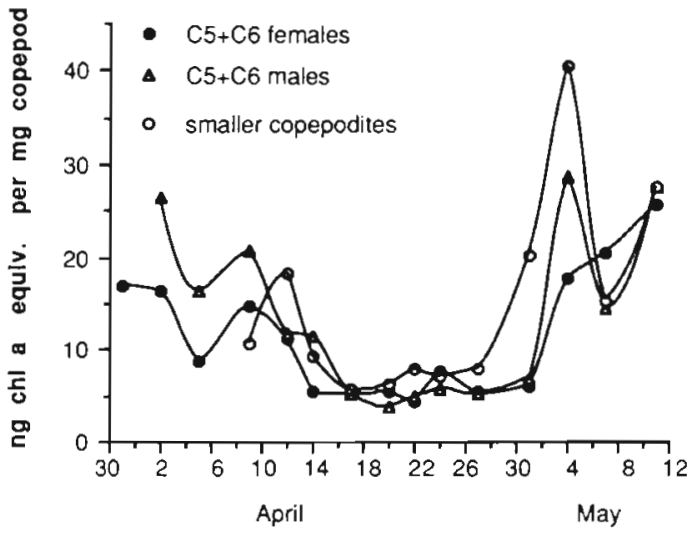

Fig. 7. Temora longicornis. Weight-specific gut fluarescence of 3 age and sex classes in the Marsdiep during spring 1990 (mean concentrations of all stages concentrated on $300 \mu \mathrm{m}$ gauze)

ranged between 6 and $26 \mathrm{ng}$ chl a $\mathrm{l}^{-1} \mathrm{~d}^{-1}$. This is less than $1 \%$ of the phytoplankton standing stock present. Thus it is concluded that grazing by $T$. longicomis did not have a significant impact on the dynamics of the spring Phaeocystis bloom. Considering the small biomass of the other copepods, this probably also holds for the whole copepod community.

\section{DISCUSSION}

The gut fluorescence method (Mackas \& Bohrer 1976) allows the study of undisturbed grazing by copepods in the field and has therefore been widely implemented for the last $15 \mathrm{yr}$. The uncertainty in the determination of gut passage times suggests that one has to be cautious deriving absolute ingestion figures from gut fluorescence measurements (e.g. Penry \& Frost 1990 and references cited therein). However, Kiørboe et al. (1982, 1985) and Peterson et al. (1990) have shown good agreement of this method with estimates obtained by the measurement of the decrease of chlorophyll and cells during incubation experiment as well as good correlation between ingestion measured with the gut fluorescence technique and egg production. Thus, for studying daily feeding rhythms or seasonal differences, as presented here, the gut fluorescence method may still be regarded as a useful tool.

Many authors have reported diel feeding rhythms in copepods (e.g. Mackas \& Bohrer 1976, Stearns 1986, Tiselius 1988) although such rhythms may also be absent (Roman et al. 1988). Baars \& Fransz (1984) and Dam (1986) found gut pigment content in Temora longicornis to be about twice as high at night as during the day. It has been proposed that light intensity is an important factor in controlling diel feeding rhythms 
Table 1 Temora longicornis grazing pressure on the 1990 phytoplankton spring bloom before, during and after the Phaeocystis dominated period. Arithmetic means of weight-specific gut fluorescence (GF), gut passage time (GPT), specific daily ration (SDR), T. longicornis biomass (TB), total phytoplankton ingestion by T. longicornis (TPI), phytoplankton standing stock (PSS) and grazing pressure (GP) as ratio TPI/PSS for copepodite stages $\mathrm{C} 5+\mathrm{C} 6$ females (f ${ }^{*}$ ), $\mathrm{C} 5+\mathrm{C} 6$ males (m*) and younger copepodites $\left(c^{*}\right)$

\begin{tabular}{|c|c|c|c|c|c|c|c|c|}
\hline Date & Group & $\begin{array}{c}\text { GF } \\
\text { (ng chl a equiv. } \\
\text { mg body } \mathrm{C}^{-1} \text { ) }\end{array}$ & $\begin{array}{c}\text { GPT } \\
(\min )\end{array}$ & $\begin{array}{c}\text { SDR } \\
(\mathrm{mgCmg} \\
\left.\text { body } \mathrm{C}^{-1} \mathrm{~d}^{-1}\right)\end{array}$ & $\begin{array}{c}\mathrm{TB} \\
\left(\mathrm{mg} \mathrm{C} \mathrm{m}^{-3}\right)\end{array}$ & $\begin{array}{c}\text { TPI } \\
\left(\mathrm{mg} \mathrm{C} \mathrm{m}^{-3} \mathrm{~d}^{-1}\right)\end{array}$ & $\begin{array}{c}\text { PSS } \\
\left(\mathrm{mg} \mathrm{C} \mathrm{m}^{-3}\right)\end{array}$ & $\begin{array}{l}G P \\
(\%)\end{array}$ \\
\hline \multirow{2}{*}{$\begin{array}{c}29 \mathrm{Mar} \\
\text { to }\end{array}$} & $f^{\cdot}$ & 34.1 & 34.9 & 0.037 & 3.8 & 0.14 & & \\
\hline & $\mathrm{m}^{\bullet}$ & 47.0 & 34.9 & 0.051 & 3.3 & 0.17 & & \\
\hline \multirow[t]{2}{*}{$12 \mathrm{Apr}$} & $c^{*}$ & 36.2 & 34.9 & 0.039 & 0.9 & 0.04 & & \\
\hline & Sum & & & & 8.1 & 0.35 & 842 & 0.04 \\
\hline $13 \mathrm{Apr}$ & $\mathrm{f}^{\cdot}$ & 14.0 & 33.1 & 0.017 & 11.7 & 0.20 & & \\
\hline to & $\mathrm{m}^{*}$ & 15.5 & 33.1 & 0.019 & 6.4 & 0.12 & & \\
\hline \multirow[t]{2}{*}{$24 \mathrm{Apr}$} & $c^{*}$ & 18.1 & 33.1 & 0.022 & 2.6 & 0.06 & & \\
\hline & Sum & & & & 20.7 & 0.38 & 969 & 0.04 \\
\hline $25 \mathrm{Apr}$ & $f^{*}$ & 37.7 & 27.6 & 0.049 & 17.6 & 0.86 & & \\
\hline to & $m^{\circ}$ & 41.3 & 27.6 & 0.054 & 8.6 & 0.46 & & \\
\hline \multirow[t]{2}{*}{$11 \mathrm{May}$} & $\mathrm{C}^{\cdot}$ & 55.5 & 27.6 & 0.073 & 3.0 & 0.22 & & \\
\hline & Sum & & & & 29.1 & 1.54 & 345 & 0.45 \\
\hline
\end{tabular}

(e.g. Stearns 1986 and references cited therein). In the highly turbid Marsdiep area, copepods are exposed to low light levels during daytime as well. Hence, they might exhibit a much less pronounced daily feeding rhythm than copepods in other areas. Sampling took place at high tide, thus varying regularly between 07:00 and 19:00 $\mathrm{h}$ with 3 shifts from evening to morning sampling in the course of this study. However, neither an increase in gut fluorescence coinciding with these shifts was observed, nor could the observed variation of gut fluorescence be correlated to sampling time. Daro (1986) likewise reported that $T$. Iongicornis lost its feeding rhythm during a Phaeocystis bloom. Diel feeding rhythms were not investigated in this study and day-night differences in feeding could have led to an underestimation of daily ingestion and consumption rates calculated. However, this would not affect the major conclusions drawn in this paper.

The observed spring increase in Temora longicornis abundance is in accordance with previous studies in the Marsdiep area (Fransz \& van Arkel 1983, Kuipers et al. 1990). The estimate for $T$. longicornis production in April (Fig. 5) was made under the assumption that biomass accumulation in the older stages reflected the average copepodite growth in the sampled waters. Fransz (1976) showed a similar spring development of T. longicornis in different areas along the Dutch coast. Assuming a daily mortality of about $10 \%$ (e.g. Bakker \& van Rijswijk 1987 and references cited therein), no advection, and a gross growth efficiency between $17 \%$ (Harris \& Paffenhöfer 1976) and $35 \%$ (e.g. Berggren et al. 1988), the observed growth of T. longicornis would require an ingestion of 70 to $140 \%$ of body weight daily. This value agrees well with rates obtained from growth experiments with $T$. longicornis cultures in the presence of excess food (Klein Breteler et al. 1990). During the Phaeocystis bloom, the calculated daily ration of $T$. longicornis, as based upon gut fluorescence measurements, amounted to only a small percentage of its body carbon, quite insufficient to cover its food demand. Even on the basis that $T$. longicornis fed solely on Phaeocystis colonies with a $\mathrm{C} / \mathrm{chl}$ a ratio ranging between 55 and 245 (Lancelot \& Billén 1990 ) and converted the mucus with the same gross growth efficiency (which is unlikely because it has a low nitrogen content), a considerable gap between autotrophic food intake and energy demand would still remain.

In order to explain the high growth rates, the hypothesis is put forward that Temora longicornis switched to a heterotrophic food source, at least during the Phaeocystis dominated period. We here consider 2 major possibilities for this food source: detritus, probably coated with bacteria, and microzooplankton. Unfortunately, there is very little information on the quality and quantity of detritus in the Marsdiep and to what extent detritus might be utilized by $T$. longicornis. However, during the Phaeocystis dominated period a bloom of ciliates was present exceeding copepod biomass (R. Bak unpubl.). Protozoa are judged to be high-quality food for zooplankton (see review by Stoecker \& Capuzzo 1990), in contrast to Phaeocystis for which a biochemical investigation reports a low nutritional value (Claustre et al. 1990). If copepod grazing on Phaeocystis is affected by the availability and quality of alternative food sources, this might explain why most laboratory studies indicate that Phaeocystis, when offered alone or in mixture with 
other phytoplankton, is appropriate food, whereas field studies indicate grazing to be depressed during Phaeocystis blooms (Daro 1986, van Rijswijk et al. 1989). Laboratory grazing studies on copepods have shown higher feeding rates on ciliates compared to phytoplankton (Stoecker \& Sanders 1985, Williamson \& Butler 1986, Stoecker \& Egloff 1987), as well as positive selectivity for ciliates in mixtures with phytoplankton (Wiadnyana \& Rassoulzadegan 1989).

Ciliates are thought to be the major predator on Phaeocystis single cells (Weisse \& Scheffel-Möser 1990). If copepods are able to control ciliate abundance they may indirectly have a considerable impact on Phaeocystis bloom dynamics. Whether copepod grazing enhances or depresses Phaeocystis development will then depend on the availability and type of alternative food sources. We are continuing research on this topic and suggest that further grazing studies should concentrate more on heterotrophic microzooplankton and its possible function as a link between phytoplankton and larger zooplankton.

Acknowledgements. This work was financially supported by the $\mathrm{EEC}$ and is a contribution to the $\mathrm{EEC}$ research project on the Dynamics of Phaeocystis blooms in nutrient enriched coastal zones (Contract nos. B/89000615 \& EV4V-0102B(GDF). We thank Prof. Dr J. Lenz, Dr W. C. M. Klein Breteler, Dr M. A. Baars, Dr C. Bakker, Dr R. Riegman, Dr M. Veldhuis, B. Bak and A. Rowe for their constructive comments on the manuscript.

\section{LITERATURE CITED}

Baars, M. A., Fransz, H. G. (1984). Grazing pressure of copepods on the phytoplankton stock of the central North Sea. Neth. J. Sea Res. 18(1/2): 120-142

Baars, M. A., Oosterhuis, S. S. (1984). Diurnal feeding rhythms in North Sea copepods measured by gut fluorescence digestive enzyme activity and grazing on labelled food. Neth. J. Sea Res. 18(1/2): $97-119$

Bakker, C., van Rijswijk, P. (1987). Development time and growth rate of the marine calanoid copepod Temora longicornis as related to food conditions in the Oosterschelde Estuary (Southern North Sea). Neth. J. Sea Res. 21(2): $125-141$

Berggren, U., Hansen, B., Kiørboe, T (1988). Food size spectra, ingestion and growth of the copepod Acartia tonsa during development: implications for determination of copepod production. Mar. Biol. 99: 341-352

Cadée, G. C. (1986). Recurrent and changing seasonal patterns in phytoplankton of the westernmost inlet of the Dutch Wadden Sea from 1969 to 1985. Mar Biol. 93: $281-289$

Claustre, H., Poulet, S. A., Williams, R., Marty, J.-C., Coombs, S., Ben Mlih, F., Hapette, A. M., Martin-Jezequel, V. (1990). A biochemical investigation of a Phaeocystis sp. bloom in the Irish Sea. J. mar. biol. Ass. U.K. 70: 197-207

Cowles, T J., Olson, R. J., Chisholm, S. W. (1988). Food selection by copepods: discrimination on the basis of food quality. Mar. Biol. 100: 41-49

Dam, H. G. (1986). Short-term feeding of Temora longicornis Müller in the laboratory and the field. J. exp. mar. Biol. Ecol. 99: 149-161

Dam, H. G., Peterson, W. T. (1988). The effect of temperature on the gut clearance rate constant of planktonic copepods. J. exp. mar. Biol. Ecol. 123: 1-14

Daro, M. H. (1986). Field study of the diel, selective and efficiency feeding of the marine copepod Temora Iongicornis in the Southern Bight of the North Sea. In: van Grieken, R., Wollast, R. (eds.) Proc of the Conference 'Progress in Belgian Oceanographic Research', Brussels, 1985. p. $250-263$

Estep, K. W., Nejstgaard, J. C., Skjoldal, H. R., Rey, F. (1990). Predation by copepods upon natural populations of Phaeocystis pouchetii as a function of the physiological state of the prey. Mar. Ecol. Prog. Ser. 67(3): 235-249

Fransz, H. G. (1976). The spring development of calanioid copepod populations in the Dutch coastal waters as related to primary production. In: Persoone, G., Jaspers, E. (eds.) Population dynamics of marine organisms in relation with nutrient cycling in shallow waters. Proc. 10th Eur. Mar. Biol. Symp., Vol 2. Universa Press, Wetteren, p. $247-269$

Fransz, H. G., van Arkel, W. (1983). Fluctuation and succession of common pelagic copepod species in the Dutch Wadden Sea. In: Boutler, J. (ed.) Proc. 17th Eur. Mar. Biol. Symp. Oceanol. Acta Vol. spéc., p. 87-91

Gibson, J. A. E., Garrick, R. C., Burton, H. R., McTaggert, A. R. (1990). Dimethylsulfide and the alga Phaeocystis pouchetii in Antarctic coastal waters. Mar Biol. 104: 339-346

Hansen, B., Tande, K. S., Berggren, U. C. (1990). On the trophic fate of Phaeocystis pouchetii (Hariot). III. Functional responses in grazing demonstrated on juvenile stages of Calanus finmarchicus (Copepoda) fed diatoms and Phaeocystis J. Plankton Res. 12(6): 1173-1187

Harris, R. P., Paffenhöfer, G.-A. (1976). The effect of food concentration on cumulative ingestion and growth efficiency of two small marine planktonic copepods. J. mar. biol. Ass. U.K. 56: 875-888

Huntley, M., Tande, K., Eilertsen, H. C. (1987). On the trophic fate of Phaeocystis pouchetii (Hariot). II. Grazing rates of Calanus hyperboreus (Krøyer) on diatoms and different size categories of $P$. pouchetii. J. exp. mar. Biol. Ecol. 110: $197-212$

Jahnke, J., Baumann, M. E. M. (1987). Differentiation between Phaeocystis pouchetii (Har.) Lagerheim and Phaeocystis globosa Scherffel. I. Colony shapes and temperature tolerances. Hydrobiol. Bull. 21(2): 141-147

Kiorboe, T., Moehlenberg, F., Nicolajsen, H. (1982). Ingestion rate and gut clearance in the planktonic copepod Centropages hamatus (Liljeborg) in relation to food concentration and temperature. Ophelia 21(2): 181-194

Kiørboe, T., Moehlenberg, F., Hamburger, K. (1985). Bioenergetics of the planktonic copepod Acartia tonsa: relation between feeding, egg production, and respiration, and composition of specific dynamic action. Mar Ecol. Prog. Ser. 26: 85-97

Klein Breteler, W. C. M., Gonzalez, S. R. (1988). Influence of temperature and food concentration on body size, weight and lipid content of two calanoid copepod species. Hydrobiol. 167/168: 201-21.0

Klein Breteler, W. C. M., Schogt, N., Gonzales, S. R. (1990). On the role of food quality in grazing and development of life stages, and genetic change of body size during 
cultivation of pelagic copepods. J. exp. mar. Biol. Ecol. 135: $177-189$

Kuipers, B. R., Gaedke, U., Enserink, L., Witte, H. (1990). Effect of ctenophore predation on mesozooplankton during a spring outburst of Pleurobrachia pileus. Neth. J. Sea Res. 26(1): 111-124

Lancelot, C., Billén, G., Sournia, A., Weisse, T., Colijn, F., Veldhuis, M. J. V., Davies, A., Wassman, P. (1987). Phaeocystis blooms and nutrient enrichment in the continental coastal zones of the North Sea. Ambio 16(1): 38-46

Lancelot, C., Billén, G. (1990). Joint EEC project on the dynamics of Phaeocystis blooms in nutrient enriched coastal zones. 2nd. Ann. Prog. Rep., University of Brussels

Lancelot-van Beveren, C. (1980). A statistical method to estimate the biochemical composition of phytoplankton in the Southern Bight of the North Sea. Estuar coast. mar. Sci. 10: $467-478$

Lebour, M. V. (1922). The food of plankton organisms. J. mar. biol. Ass. U.K. : $644-677$

Lorenzen, C. J. (1967). Determination of chlorophyll and pheo-pigments: spectrophotometric equations. Limnol. Oceanogr. 12: 343-346

Mackas, D., Bohrer, R. (1976). Fluorescence analysis of zooplankton gut contents and an investigation of diel feeding patterns. J. exp. mar. Biol. Ecol. 25: 77-85

Omori, M. (1969). Weight and chemical composition of some important oceanic zooplankton in the North Pacific Ocean. Mar. Biol. 3: 4-10

Penry, D. L., Frost, B. W. (1990). Re-evaluation of the gutfullness (gut fluorescence) method for inferring ingestion rates of suspension-feeding copepods. Limnol. Oceanogr. 35(5): $1207-1214$

Peterson, W. T., Painting, S. J., Barlow, R. (1990). Feeding rates of Calanoides carinatus: a comparison of five methods including evaluation of the gut fluorescence method. Mar. Ecol. Prog. Ser. 63: 85-92

Postma, H. (1954). Hydrography of the Dutch Wadden Sea. Archs néérl. Zool. 10: 405-511

Radach, G., Berg, J., Hagmeier, E. (1990). Long-term changes of the annual cycles of meteorological, hydrographic, nutrient and phytoplankton time series at Helgoland and at LV ELBE 1 in the German Bight. Cont. Shelf Res. 10(4) $305-328$

Riemann, B., Søndergaard, M., Schierup, H.-H., Bosselmann, G., Hansen, J., Nielsen, B. (1982). Carbon metabolism during a spring diatom bloom in the eutrophic Lake Mosso. Int. Rev. ges. Hydrobiol. 67: 145-185

Roman, M. R., Ashton, K. A., Gauzens, A. L. (1988). Day/night differences in the grazing impact of marine copepods. Hydrobiol. 167/168: 21-30

Savage, R. E. (1932). Phaeocystis and herring shoals. J. Ecol. 20: $326-340$

Schnack, S. B. (1983). On the feeding of copepods on Thalassiosira partheneia from the Northwest African upwelling

This article was submitted to the editor area. Mar. Ecol. Prog. Ser. 11: 49-53

Sieburth, J. McN. (1960). Acrylic acid, and 'antibiotic' principle in Phaeocystis in Antarctic waters. Science 132: 676-677

Stearns, D. E. (1986). Copepod grazing behavior in simulated natural light and its relation to nocturnal feeding. Mar. Ecol. Prog. Ser. 30: 65-76

Steele, J. H. (1974). The structure of marine ecosystems. Harvard University Press, Cambridge, Massachusetts

Stoecker, D. K., Egloff, D. A. (1987). Predation by Acartia tonsa Dana on planktonic ciliates and rotifers. J. exp. mar. Biol. Ecol. 110:53-68

Stoecker, D. K., McDowell Capuzzo, J. (1990). Predation on Protozoa: its importance to zooplankton. J. Plankton Res. 12(5): 891- 908

Stoecker, D. K., Sanders, N. K. (1985). Differential grazing by Acartia tonsa on a dinoflagellate and a tintinnid. J. Plankton Res. 7(1): 85-100

Tande, K. S., Banmstedt, U. (1987). On the trophic tate of Phaeocystis pouchetii. I. Copepod feeding rates on solitary cells and colonies of $P$. pouchetii. Sarsia 72; 313-320

Tiselius, P. (1988). Effects of diurnal feeding rythms, species composition and vertical migration on the grazing impact of calanoid copepods in the Skagerrak and Kattegat. Ophelia 28(3): 215-230

Turner, S. M., Malin, G., Liss, P. S., Harbour, D. S., Holligan, P. M. (1988). The seasonal variation of dimethylsulfide and dimethylsulfoniopropionate concentrations in nearshore waters. Limnol. Oceanogr. 33: 364-375

Utermöhl, H. (1958). Zur Vervollkommnung der quantitativen Phytoplankton-Methodik. Mitt. int. Ver. theor angew. Limnol. 9

van Rijswijk, P., Bakker, C., Vink, M. (1989). Daily fecundity of Temora longicornis (Copepoda Calanoida) in the Oosterschelde Estuary (SW Netherlands). Neth. J. Sea Res. 23(3): 293-303

Verity, P. G., Smayda, T. J. (1989). Nutritional value of Phaeocystis pouchetii (Prymnesiophyceae) and other phytoplankton for Acartia spp. (Copepoda): ingestion, egg production, and growth of nauplii. Mar. Biol. 100: 161-171

Wassmann, P., Vernet, M., Mitchell, B. G., Rey, F. (1990). Mass sedimentation of Phaeocystis pouchetii in the Barents Sea. Mar. Ecol. Prog Ser. 66: 183-195

Weisse, $T$ (1983). Feeding of calanoid copepods in relation to Phaeocystis pouchetii blooms in the German Wadden Sea area off Sylt. Mar. Biol. 74: 87-94

Weisse, T., Scheffel-Möser, U. (1990). Growth and grazing loss rates in single-celled Phaeocystis sp. (Prymnesiophyceae). Mar. Biol. 106: 153-158

Wiadnyana, N. N., Rassoulzadegan, F. (1989). Selective feeding of Acartia clausi and Centropages typicus on microzooplankton. Mar. Ecol. Prog. Ser. 53: 37-45

Williamson, C. E., Butler, N. M. (1986). Predation on rotifers by the suspension-feeding calanoid copepod Diaptomus pallidus. Limnol. Oceanogr. 31(2): 393-402

Manuscript first received: May 17, 1991

Revised version accepted: October 31, 1991 